\title{
India's ballistic success
}

\section{New DelhI}

INDIA last week signalled its entry into the small group of nations capable of building ballistic missiles with the successful test firing of the 'Agni' intermediate-range ballistic missile. Twice postponed because of technical problems, the launch took place on 22 May from the defence range in Chandipur on Orissa's east coast amid great publicity.

Except for a cryptic announcement that the test was a success, the government released few details of the flight. The Defence Ministry said the missile "followed the pre-determined path, impacted on the designated area in the Bay of Bengal and fully met the objectives of the mission". The Defence Research Development Organisation (DRDO), which developed the missile, claimed that the test was essential to test advanced technologies but said nothing about the primary aim of the mission: testing the first home-made reentry heat shield, a key component of a weapons delivery system.

Agni is the third missile to come out of the $\$ 500$-million integrated guided-missile programme of DRDO. It is claimed to be almost fully indigenous, one reason why India could go ahead with its test in the face of opposition from the United States. The two-stage, 14-tonne 19-metre tall missile is said to be able to deliver a onetonne warhead to a target up to $2,500 \mathrm{~km}$ away within 15 minutes. This range includes some Chinese cities.

In 1987, India tested a surface-to-air missile, Trishul, and last year demonstrated the surface-to-surface missile, Prithvi, with a range of $250 \mathrm{~km}$, sufficient to reach targets in Pakistan. It is no surprise that the launch of Agni evoked angry reactions from Pakistan, which called it a threat to regional peace.

The Indian Prime Minister, Rajiv Gandhi, has declared that India "is a nonviolent country with no aggressive designs on anyone". In a statement issued immediately after the launch, Gandhi assured the world that Agni "is not a nuclear weapons system". He said "it provided an option to deliver non-nuclear weapons with high precision at long ranges" and that its test was "part of continuing efforts to safeguard our independence and security by self-reliant means". Dismissing allegations that Agni will be tipped with nuclear warheads, Gandhi recalled that India, which detonated a nuclear device 15 years ago, set an example to the whole world by refusing to convert this nuclear capability into nuclear weapons. "We wish to keep it this way", he said.

But some hawks would like India to go nuclear quickly in order to deter potential aggressors. As one defence analyst put it, Agni may be a major contribution to India's negotiating strength for advancing international peace and stability.

K.S. Jayaraman

\section{SPACE ROCKETRY}

\section{Brazil's two-thirds VLS success}

\section{São Paulo}

Although still many steps behind India (see above), Brazil too showed that it is on its way to membership in the rocketry club with the succesful launch of a reducedscale version of its Satellite Vehicle Launcher (VLS) on 18 May. And, like India, Brazil is feeling the pinch as advanced nations try to prevent Third World nations from developing ballistic missiles by limiting the export of sensitive high-technology materials.

Brazil's four-stage rocket was launched from the Air Force base Barreira do Inferno ('Barrier of Hell') near Natal, in the northeastern state of Rio Grande do Norte. The rocket was a one- third scaleddown version of the planned 18-metre tall VLS rocket. The goal is to place a 120 kilogramme Data Collecting Satellite (SCD-1) into a 750 kilometre orbit. But despite the success of the test launch, the programme has been set back three years as boycotts and tight budgets take effect.

In April 1987, the group of seven industrialized nations banned the export of all materials critical to the development of rockets capable of delivering a $\mathbf{5 0 0}$ kilo- gram payload to a distance of 300 kilometres. The supply of electronic components for rocket guidance was hit hardest.

The advanced nations' concern over the Brazilian programme is heightened by the fact that it is under the control of the Brazilian Air Force rather than a civi organization. The advanced nations suspect that the next step will be to go from a space programme to the development of a ballistic missile.

A complicating factor is that Brazil, despite its rabid anti-communism, has made deals with both China and the USSR to try to gain access to advanced technology. INPE, the civilian Institute for Space Research, already has an agreement with China to build a remote-sensing satellite.

The high-technology boycott has meant considerable frustration for INPE. Its SCD-1 satellite is due to be completed later this year. But the Air Force will not now complete its rocket until 1992 rather than the planned 1989. Despite complaints from some INPE members, the military insists on waiting for the indigenous VLS to be complete rather than hire a place on a foreign launcher.

\section{Japan warms to the Cray}

\section{Tokyo}

WHILE the US government considers new ways to put pressure on the Japanese government to make them buy more US supercomputers for its research institutes and universities, Cray Research Inc. says that Japanese industry has already taken to US machines with unbridled enthusiasm.

According to Cray, Japanese companies now own nearly as many supercomputers as US companies. Sumitomo Chemical Co. has now joined the club. But the sales may not please all sectors of US industry: the computers are used to help design world-beating high-technology products.

Japanese supercomputer sales are concentrated in the private sector. In the United States, nearly two-thirds of the 142 supercomputers currently in use are in national laboratories and universities, according to Takehiko Kato of Cray Research Japan Ltd. In Japan, the reverse is true - about 80 out of 120 machines are in private companies. And it is the private sector that is growing rapidly.

Many of the machines are being used 'in house' by Japan's supercomputer manufacturers (NEC, Fujitsu and Hitachi) but they are also widely used in other industries. All of Japan's 'big five' car manufacturers (Toyota, Nissan, Mazda, Honda, and Mitsubishi Motors) use Cray computers to design new car models. Nissan has five Cray central processing units, more than any other automobile manufacturer in the world, Kato says.

Toshiba Corporation used a Cray in the development of its 1 megabit chips, which are now dominating the world market, and Sumitomo Chemical now plans to use one of the US machines for the molecular design of new chemicals. Cash-rich Japanese service companies are also buying supercomputers. Yamaichi and Daiwa securities companies are said to have ordered machines. And the information conglomerate Recruit, which is currently embroiled in a huge political scandal, leases access to two Crays that it bought second-hand from the domestic telecommunications giant Nippon Telegraph and Telephone Corporation (NTT), another Cray customer. David Swinbanks - Japan, together with Brazil and India, was last week added to the US Administration's "enemies list" as a country deemed to have engaged in unfair trading practices harmful to US exports. Specifics cited in the Japanese case were wood products, supercomputers and satellites. The list was issued under the controversial 'Super 301' provision of the 1988 Omnibus Trade Act, and requires negotiation on the 'offending' practices to be concluded within 3 years. 